\title{
Using Task-based Materials in Teaching Writing for EFL Classes in Indonesia
}

Hanna Sundari*, Rina Husnaini Febriyanti, Gustaman Saragih

Department of English Education, University of Indraprasta PGRI Jalan Nangka No. 58 C Jakarta, Indonesia

Corresponding Author: Hanna Sundari, E-mail: hanna.sundari@gmail.com

\section{ARTICLE INFO}

Article history

Received: October 14, 2017

Accepted: January 02, 2018

Published: May 01, 2018

Volume: 7 Issue: 3

Advance access: March 2018

Conflicts of interest: None

Funding: None

\begin{abstract}
Task-based language teaching has been widely used for language classroom. Using tasks as main activities, task-based materials was developed particularly for writing class. This article is intended to present the study of effectiveness of task-based materials in improving writing class for university. To accommodate the research purposes, mixed method approach was carried out by using quasi experimental research and content analysis of sentence complexity. The respondents were 210 students from writing classes as experiment and control with writing test as instrument. The results of data analysis showed that there were significant differences of writing skill to those who taught using developed task-based materials. Despite the fact that the score did not significantly differ on the aspect of writing mechanics, a developed task-based material has been proved to improve students' writing skill in the aspect of format, content, organization and grammar. Moreover, the levels of lexical complexity and accuracy from the students whose materials use task-based design are higher than those who do not use it. Then, it can be drawn a conclusion that the use of developed task-based materials brings significant effects toward writing performance.
\end{abstract}

Key words: Task-Based Language Teaching, Task-Based Materials, Teaching Writing, Writing Skill, Efl Classes, Indonesia

\section{INTRODUCTION}

Teaching writing in foreign language context brings challenges and effort. Stimulating students to deliver ideas and messages in written form into target language from students to different cultures and regions is not an easy work. As a productive skill, writing is basically the process of communicating messages in written language completed by a set of micro skills (Spratt, Pulverness, \& Williams, 2011). Writing activity is seemingly related to linguistic competences, such as grammar, vocabulary, writing mechanics and text structure. In writing, the writers have to ideas or message to express, words to convey, language construction to set the words and meaning, text organization to make meaning and context. However, these elements of writing skill are apparently complex and heavy. Consequences, learners, particularly in English as foreign language situation, find writing difficult and troublesome. In fact, subject-verb agreement and verb tenses, as basic grammar rules, are still as the causes of error in developing essay for adult EFL learners in writing class (Febriyanti \& Sundari, 2016: 79). Moreover, other linguistic items such as, grammatical structure, formatting words, and word classes have also become the sources of difficulty in writing for Indonesian students (Rahmatunisa, 2014).
In addition to linguistic aspect of writing skill, the fear of teacher's negative comments, insufficient writing practice and time pressure can be considered as source of writing anxiety in the class (Wahyuni \& Umam, 2017). Indeed, as writers in foreign language, the students are required to know the social context where the texts take place and to whom the texts are. Moreover, what the students learn in the classroom; it can also be used and applied outside the classroom for real communication. Writing activity, practice and product are not isolated merely for learning and classroom usage. Nonetheless, activity, materials and practice are authentic. Therefore, the writing product or texts produced by the students could be relevant to the real-world language. Therefore, a set of task-based materials for writing class in English as foreign language context has been developed based on the principles of task-based lesson for university students. This current study purposes to answer the following questions: a) Are there any significant effects the use of developed task-based materials towards writing performance indicator in the terms format, writing mechanics, content, organization, and grammar and sentences? And b) How are the levels of lexical complexity and accuracy from the students who taught using developed task-based materials compared to those who do not? 


\section{LITERATURE REVIEW}

One of the language teaching approach which focuses on learning to communicate through interaction is task-based language teaching (TBLT). TBLT is an approach of the use of tasks as the core unit of analysis, planning and instruction (Richards \& Rodgers, 2001). It was firstly initiated when Wilkins (1976) argued the distinction of synthetic and analytical approach to language pedagogy. Synthetic approaches use language as center of analysis to be taught; meanwhile, analytical approaches take learners and the purposes as considerations (Nunan, 2010: 136-137). Then, task-based is part of analytical approaches in which language presented in holistic and learners are asked to break down and analyze it.

Having been formed as part of communicative language teaching, task-based instruction has, according to Feez (1998: 17 cited by Richards \& Rodgers, 2001: 224) several key assumptions as: 1) The focus is on process rather than product, 2) Basic elements are purposeful activities and tasks that emphasize communication and meaning. 3) Learners learn language by interacting communicatively and purposefully while engaged in activities and tasks, 4) Activities and tasks might need to achieve in real life and have pedagogical purpose specific to the classroom, and 5) Activities and task of a task-based syllabus are sequenced according to difficulty. In the other words, task-based approach advocates a task as central in teaching.

A task itself is defined variously. In general term, Long (1995, in Nunan, 2006: 14) stated that a task is piece of work undertaken for oneself or for others, freely or for some reward, for example painting a fence, dressing a child, and filling out a form. These are then called as a real world or target task definition. A task is related to everyday life and activity. For a language acquisition view, Ellis (2003, cited in Nunan, 2006: 16) wrote a task as a workplan that requires learner to process language pragmatically in order to achieve an outcome. By performing task, students are expecting to develop their language proficiency; at least they are competent to perform the targeted task. Then Nunan (2006: 17) summarized the definition of task in language teaching perspectives. According to him, a task is a piece of classroom work requiring learners in comprehending, manipulating, producing, or interacting in the target language; at the same time, they more focus on organizing grammatical knowledge to express meaning, rather than manipulating form. It can be stated that, when doing task, the students perform language activity by manipulating meaning from their prior knowledge of language, and they also enhance language development from what they do not know. Moreover, Nunan (2010: 138) defined a task in the real world (target task) becomes pedagogical tasks which is what the students do in the classroom to activate and develop language skills, yet they are still related to real-world.

In developing materials using TBLT, Long and Crookes (1993, in Tabar \& Alavi, 2013) proposed the steps in design and development task-based design: 1) a comprehensive need analysis, 2) diagnosis of learner needs, 3) identification of target tasks learners, 4) classification of target tasks into task types, 5) selection of pedagogical tasks for the class- room, and 6) sequencing of pedagogical tasks. From the syllabus development, it can be listed a set of materials needed for the class. Concerning to the lesson using task-based principles, Ellis (2006: 20) concluded three common phases as a chronology of task-based lesson. Pre-task is the first phase including various activity before they start the task. At second, during task is the phase around the task itself. Post-task as a final phase is as following-up of task performance. Taskbased lesson framework can be seen on the table below.

Task-based language teaching has been widely applied in language classes. Moreover, the research regarding to taskbased has also been extensively conducted. Research by Mao (2012) and Kumara, Padmadewi, \& Suarnajaya (2013) showed that the task-based approach is effective in reading comprehension. Besides, Nahavandi (2011) investigated and proved that task-based activities have positive effects on EFL learners' reading comprehension. At writing skill, studies by Kusnawati (2014) found that TBLT has increased understanding writing process and writing skill. Furthermore, Tabar \& Alavi (2013)'s research has proved that the application of task-based brings learners with different opportunities to plan performing written tasks in different levels of cognitive complexity. With those previous research, this current study addresses to explore the application of developed task-based materials in writing class for university students.

\section{METHOD}

The purpose of this current research was to find out a comprehensive effect of use of developed task-based materials for writing class at one private university in Jakarta. The developed task-based materials have been designed using the steps of development of task based syllabus by Long and Crookes (1993). After that, the materials selected, sequenced, and presented based on the three phases of taskbased lesson (Ellis, 2006). To accommodate the research purpose, mixed method approach was carried out. According to Creswell (2012: 535), a mixed method design is a procedure in collecting, analyzing and mixing both quantitative and qualitative methods in a single study or a series of studies to understand a research problem. By doing mixed method, it provides a better understanding of how effective developed task-based materials for writing class and in what aspect of writing skill it is more effective.

The research participants were 210 students who enrolled writing class in English Education major at one private University in Jakarta. Using quasi experimental research, the study was conducted on post-test only design for both experiment and control classes. The task-based lesson and developed task-based materials were treated to experiment group on June, 2017. Then, the students from both groups were assigned to write an essay by choosing one of given topics. The instrument used for collecting data was writing test. The essays written by the students were then rated using scoring rubric proposed by Oshima and Hogue (2007). The scores were gained based on the elements of essay scoring rubric: format, writing mechanics, content, organization, and grammar and sentence. The obtained data were then analyzed using SPSS. 
To support quantitative analysis, the content analysis of sentence complexity was selected to figure out the level of accuracy and lexical complexity. According to Skehan (1998 in (Abdi, Eslami, \& Zahedi, 2012), three dimensions of language production are accuracy, complexity and fluency. Accuracy is the degree of language produced conforms to target language. Ellis (2003 in Ahmed, Jamilah, \& Bidin, 2016) noted that accuracy refers to the learner's ability to produce error free target language. Learner accuracy was calculated by using this formula.

Leamers 'L2 Accuarcy $=\frac{\text { Total number of error free clauses of L2 }}{\text { Total number of clauses of L2 sample }}$

Meanwhile, complexity refers to making use of interlanguage structures that are complicated and structured. The formula for calculating lexical complexity is displayed below.

L2 Complexity $($ lexical $)=\frac{\text { Total } \text { number of open class words }}{\text { Total number of L } 2 \text { words }} \times 100$

The sample were 20 worksheets taken randomly from both groups. After that, the result of both data from control and experiment groups are analyzed and compared.

\section{RESULT AND DISCUSSION}

This present study aims at exploring the effect of developed task-based materials for EFL writing class at university level. Both quantitative and qualitative data analysis has been applied to find out the effect of developed task-based materials on writing performance. The quantitative results from writing test are displayed below.

The scores on the table show that four out of five aspects in writing skill provides higher mean scores as well as the scores of $\mathrm{T}_{\text {obs from }}$ those aspects are higher, which means there are significant effects. These results indicate that developed

Table 1. A Framework for designing taskbased lesson (Ellis, 2006: 20)

\begin{tabular}{ll}
\hline Phase & Examples of options \\
\hline Pre-task & Framing the activity \\
& Planning time \\
& Doing a similar task \\
During task & Time pressure \\
& Number of participants \\
Post-task & Learner report \\
& Consciousness-raising \\
& Repeat task \\
\hline
\end{tabular}

task-based materials used in writing class may significantly enhance the students' writing performance in the aspects of format, content, organization, and grammar and sentence. To more details, given tasks on the developed materials help and facilitate students in designing format of text; at the same time, they could stimulate ideas and topics so that the content of text is more qualified. In addition to format and content, tasks used on developed materials might give explicit knowledge of grammar rules and text organization to build consciousness and awareness of what they learn and what is expected from them. This seems probably similar to the functions of a task that it is intended to language use either productive or receptive and oral or written skills on organizing linguistic knowledge to convey meaning as communicative act (Nunan, 2006).

Despite the fact that developed task-based materials significantly effects writing performance on those four aspects of writing, writing mechanics is the only aspect that does not give significant influence on students writing. Writing mechanics refers to punctuation, capitalization and spelling. In fact, these technical systems seem frequently neglected for written communication either in academic work or in real-world language. Moreover, task-based approach, according to Skehan (1998, in Nunan, 2006), primarily focuses on meaning and task completion is priority.

In addition to statistical analysis of each aspect on writing skill, it has also been calculated scores of writing performance for both experiment and control groups. The mean scores from experiment group, 79.52, is higher than it is from control group, 71.03. It indicates that writing performance from group treated by developed task-based materials is fairly better. Furthermore, from t-test calculation, $\mathrm{t}_{\mathrm{obs}}$ is also higher than $\mathrm{t}_{\text {critical }} 11.257>1.968$. It can be stated that, in general, developed task-based materials give a significant effect toward writing performance. These results may support the previous research in writing course. Task-based approach help students learning language in journalism (Widayanti, 2011), and the use of task-based learning principles improve writing skills in general (Kusnawati, 2014). The findings of current research support the previous studies which stated that the application of TBLT give significant effects in language skills (Kumara et al., 2013; Mao, 2012; Nahavandi, 2011; Tabar \& Alavi, 2013).

Aside from statistical analysis, the essays made by the students have also been analyzed from the perspective of sentence complexity: lexical complexity and accuracy for both groups. The Table 3 shows the different scores of lexi-

Table 2. Results of statistical analysis

\begin{tabular}{|c|c|c|c|c|c|}
\hline \multirow[t]{2}{*}{ Aspects } & \multicolumn{2}{|c|}{ Mean } & \multirow[t]{2}{*}{ Tobserved } & \multirow[t]{2}{*}{ Tcritical } & \multirow[t]{2}{*}{ Descriptions } \\
\hline & Experiment & Control & & & \\
\hline Format & 4.78 & 4.32 & 3.88 & 1.968 & Significant \\
\hline Writing mechanics & 4.99 & 4.98 & 0.579 & 1.968 & Not significant \\
\hline Content & 14.01 & 12.27 & 6.401 & 1.968 & Significant \\
\hline Organization & 28.97 & 26.35 & 9.588 & 1.968 & Significant \\
\hline Grammar \& Sentence & 26.76 & 23.09 & 13.674 & 1.968 & Significant \\
\hline
\end{tabular}


Table 3. The scores of complexity level

\begin{tabular}{|c|c|c|c|c|c|c|c|}
\hline \multicolumn{4}{|c|}{ Experiment group } & \multicolumn{4}{|c|}{ Control group } \\
\hline Sample & Total words & Content words & Complexity & Sample & Total words & Content words & Complexity \\
\hline 1 & 341 & 136 & 39.88 & 1 & 171 & 83 & 48.54 \\
\hline 2 & 229 & 100 & 43.67 & 2 & 154 & 61 & 39.61 \\
\hline 3 & 365 & 159 & 43.56 & 3 & 229 & 107 & 46.72 \\
\hline 4 & 330 & 162 & 49.09 & 4 & 542 & 247 & 45.57 \\
\hline 5 & 198 & 99 & 50.00 & 5 & 187 & 81 & 43.32 \\
\hline 6 & 203 & 89 & 43.84 & 6 & 231 & 73 & 31.60 \\
\hline 7 & 142 & 74 & 52.11 & 7 & 207 & 70 & 33.82 \\
\hline 8 & 118 & 63 & 53.39 & 8 & 129 & 50 & 38.76 \\
\hline 9 & 412 & 212 & 51.46 & 9 & 176 & 69 & 39.20 \\
\hline 10 & 132 & 64 & 48.48 & 10 & 208 & 77 & 37.02 \\
\hline 11 & 281 & 75 & 26.69 & 11 & 312 & 130 & 41.67 \\
\hline 12 & 204 & 79 & 38.73 & 12 & 280 & 121 & 43.21 \\
\hline 13 & 119 & 52 & 43.70 & 13 & 422 & 161 & 38.15 \\
\hline 14 & 295 & 145 & 49.15 & 14 & 308 & 139 & 45.13 \\
\hline 15 & 193 & 81 & 41.97 & 15 & 307 & 133 & 43.32 \\
\hline 16 & 221 & 96 & 43.44 & 16 & 206 & 88 & 42.72 \\
\hline 17 & 152 & 64 & 42.11 & 17 & 224 & 114 & 50.89 \\
\hline 18 & 261 & 130 & 49.81 & 18 & 319 & 153 & 47.96 \\
\hline 19 & 233 & 91 & 39.06 & 19 & 332 & 152 & 45.78 \\
\hline 20 & 217 & 104 & 47.93 & 20 & 225 & 128 & 56.89 \\
\hline Total & & & 898.06 & & & & 859.89 \\
\hline
\end{tabular}

cal complexities from experiment and control groups.

From Table 3, it can be seen that the total score of (lexical) complexity level from experiment group is relatively higher than it is from control group, 898.06 $>859.89$. It has proved that the essays made by the students using developed task-based materials have higher variety and richness of lexicon in the forms of verbs, nouns, adverbs, and adjectives. In addition to lexical complexity level, the Table 4 displays the result of accuracy level.

Table 4 describes the level of accuracy for both groups. It is shown that total score of accuracy level from experiment group is pretty much different from score of control group, $14.62>11.45$. Having a higher score of accuracy level, it has proven that the students in group using developed taskbased materials write essays in higher accuracy. The students succeed in controlling error and handling difficult structures. As a consequence, they perform more accurate on writing essays.

Based on scores on complexity and accuracy levels, developed task-based materials has proved in improving students' writing performance. Tasks given in the class stimulate students to use various vocabulary; furthermore, they build student awareness of grammar knowledge. Consequently, the essays made by the students who taught using developed task-based materials show more variety in vocabulary and accuracy in language structures. This findings support the research by Ahmed, Jamilah, \& Bidin (2016) in which the treatment of TBLT has increased writing skill and improved second language performance indicators in the terms of complexity, fluency, and accuracy.

\section{CONCLUSION}

This current research purposes to examine the use of developed task-based materials in EFL writing class at university level. The findings show that developed task-based materials, or task-based approach in general, give significant effects on writing performance in the forms of format, content, organization, and grammar and sentence. To be more specific, developed task-based materials succeed in fostering student to use and build various vocabulary; at the same time, tasks given in the class develop students' awareness of language accuracy. In general, giving tasks based on the learner needs facilitate the students to use language they know and to improve what they do not know. Moreover, authentic tasks are enable the students to perform activity inside and outside the classroom. Therefore, the activity and language outcome are relevant to the use of language in real world.

\section{ACKNOWLEDGEMENTS}

The authors would like to send our gratitude to Ministry of Research, Technology and Higher Education of Indonesia through the schema of Penelitian Produk Terapan (PPT) 2017 for support and funding. Moreover, we would like to say our thankfulness to our colleagues in LPPM Indraprasta PGRI University Jakarta for their assistances and helps. 
Table 4. The scores of accuracy level

\begin{tabular}{|c|c|c|c|c|c|c|c|}
\hline \multicolumn{4}{|c|}{ Experiment group } & \multicolumn{4}{|c|}{ Control group } \\
\hline Sample & Total clause & $\begin{array}{l}\text { Total error } \\
\text { free clause }\end{array}$ & Accuracy & Sample & Total clause & $\begin{array}{l}\text { Total error } \\
\text { free clause }\end{array}$ & Accuracy \\
\hline 1 & 27 & 20 & 0.74 & 1 & 12 & 6 & 0.50 \\
\hline 2 & 12 & 7 & 0.58 & 2 & 11 & 4 & 0.36 \\
\hline 3 & 20 & 17 & 0.85 & 3 & 12 & 8 & 0.67 \\
\hline 4 & 22 & 15 & 0.68 & 4 & 27 & 17 & 0.63 \\
\hline 5 & 19 & 16 & 0.84 & 5 & 12 & 8 & 0.67 \\
\hline 6 & 19 & 18 & 0.95 & 6 & 19 & 12 & 0.63 \\
\hline 7 & 8 & 6 & 0.75 & 7 & 15 & 8 & 0.53 \\
\hline 8 & 9 & 7 & 0.78 & 8 & 6 & 2 & 0.33 \\
\hline 9 & 27 & 25 & 0.93 & 9 & 12 & 10 & 0.83 \\
\hline 10 & 7 & 4 & 0.57 & 10 & 21 & 17 & 0.81 \\
\hline 11 & 14 & 9 & 0.64 & 11 & 22 & 19 & 0.86 \\
\hline 12 & 12 & 9 & 0.75 & 12 & 15 & 5 & 0.33 \\
\hline 13 & 7 & 5 & 0.71 & 13 & 24 & 17 & 0.71 \\
\hline 14 & 12 & 8 & 0.67 & 14 & 13 & 2 & 0.15 \\
\hline 15 & 13 & 9 & 0.69 & 15 & 20 & 14 & 0.70 \\
\hline 16 & 16 & 10 & 0.63 & 16 & 9 & 6 & 0.67 \\
\hline 17 & 10 & 7 & 0.70 & 17 & 15 & 8 & 0.53 \\
\hline 18 & 16 & 14 & 0.88 & 18 & 11 & 7 & 0.64 \\
\hline 19 & 15 & 9 & 0.60 & 19 & 20 & 12 & 0.60 \\
\hline 20 & 16 & 11 & 0.69 & 20 & 14 & 4 & 0.29 \\
\hline Total & & & 14.62 & & & & 11.45 \\
\hline
\end{tabular}

\section{REFERENCES}

Abdi, M., Eslami, H., \& Zahedi, Y. (2012). The impact of pre-task planning on the fluency and accuracy of Iranian EFL learners, oral performance. Procedia - Social and Behavioral Sciences, 69, 2281-2288. https://doi. org/10.1016/j.sbspro.2012.12.199

Ahmed, R. Z., Jamilah, S., \& Bidin, B. (2016). The Effect of Task Based Language Teaching on Writing Skills of EFL Learners in Malaysia. Open Journal of Modern Linguistics, 6(June), 207-218.

Creswell, J. W. (2012). Educational research: Planning, conducting, and evaluating quantitative and qualitative research. Educational Research (Vol. 4). Boston: Pearson Education. https://doi.org/10.1017/ CBO9781107415324.004

Ellis, R. (2006). The methodology of task-based teaching. Asian EFL Journal. Retrieved from http://www.academia.edu/download/30635077/September_2006_Proceedings_final920.pdf\#page $=19$

Kumara, G., Padmadewi, N., \& Suarnajaya, I. W. (2013). The Effect of Task-based Language Teaching and English Grammar Toward Reading Comprehension of the Second Semester Students. Jurnal Pendidikan Bahasa Inggris, 1 .

Kusnawati, T. (2014). Penggunaan metode Task-based Learning untuk Meningkatkan Keterampilan Menulis Mahasiswa. Bahasa \& Sastra, 14(1), 93-108.
Mao, Z. (2012). The Application of Task-based Language Teaching to English Reading Classroom. Theory and Practice in Language Studies, 2(11), 2430-2438. https:// doi.org/10.4304/tpls.2.11.2430-2438

Nahavandi, N. (2011). The Effect of Task-based Activities on EFL Learners â $€^{\mathrm{TM}}$ Reading Comprehension. Advances in Language and Literary Studies, 2(1), 56-69. https://doi.org/10.7575/aiac.alls.v.2n.1p.56

Nunan, D. (2006). Task-based Learning in the Asian Context: Defining "Task." The Asian EFL Journal Quaterly, $8(3), 12-18$.

Nunan, D. (2010). A Task-based Approach to Materials Development. Advances in Language and Literary Studies, 1(2), 135-160. https://doi.org/10.7575/aiac. alls.v.1n.2p.135

Oshima, A., \& Hogue, A. (2007). Introduction to Academic Writing: Third Edition. New York: Pearson Education, Inc.

Rahmatunisa, W. (2014). Problems faced by Indonesian EFL learners in writing argumentative essay. English Review: Journal of English Education, 3(1), 1-9. Retrieved from http://journal.uniku.ac.id/index.php/ERJEE

Richards, J., \& Rodgers, T. (2001). Approaches and Methods in Language Teaching. Cambridge University Press. Cambridge: Cambridge University Press. https://doi. org/10.1016/0346-251X(87)90017-0 
Tabar, N. A., \& Alavi, S. M. (2013). A Comparative Study of the Effects of Task-Based Writing under Different PreTask Planning Conditions on Intermediate EFL Learners 'Written Performance in Personal and Decision-Making Tasks, 5(8), 970-978.

Wahyuni, S., \& Umam, M. K. (2017). an Analysis on Writing Anxiety of Indonesian Efl College Learners. Jeels,
4(1), 103-126. Retrieved from http://jurnal.stainkediri. ac.id/index.php/jeels/article/view/333

Widayanti, M. J. A. (2011). Enhancing Students' writing Skill Through Task-based Approach. Language Circle: Journal of Language and Literature, VI(1/October), 27-39. 